\title{
DNA 变异结构的扫描隧道显微镜研究
}

\author{
白春礼叶 坚 龚立三戴长春 王大文高 凡 顾建国
}

( 中国科学院化学研究所, 北京 100080)

\section{关键词 DNA 结构、三链 DNA、扫描隧道显微镜}

脱徐核糖核酸 (DNA) 是生命活动的主要遗传物质, 它在不同的环境下可以产生结构变化, 如经加热处理等会使 DNA 的双螺旋发生解旋等变化.

最近有人用扫描隧道显微镜 (STM) 在人气下直接观察了裸露的 B, A, Z-DNA 的双螺旋 结构和单链 DNA 的结构 ${ }^{[1-2]}$, 证明了 STM 是研究核酸结构的有力工, 具. 但经过变性处理 的 DNA 结构的直接观察尚未见文献报道. 我们用自行研制的 STM ${ }^{[3]}$, 直接观察到 DNA 变异结构的一些存在形态.

实验用样品是华美生物工程公司生产的噬菌体 Lambda DNA-Hind III (Fragment Sizes: $23,130,9416,6557,4361,2322,2027,564,125)$. 将这种 DNA 的水溶液经加热到其 $T_{\mathrm{m}}$ 点之上的 $100^{\circ} \mathrm{C}$ 约 $15 \mathrm{~min}$, 然后快速降温到 $0^{\circ} \mathrm{C}$. 将此经过处理的稀溶液滴到新鲜剥离的裂 解石墨表面, 待溶剂蒸发后在室温条件下用 STM 直接进行观察.

图 1 (a) 是我们用 STM 得到的一种竬状三链 DNA 变异结构图象, 其宽约为 $30 \AA$, 与未经变 性处理的右手双螺旋结构形成鲜明对比. 在样品的不同部位, 我们还观察到由双螺旋结构片 断与三链辨状结构片段的衔接结构 (图 1 (b ) ) 、右手双螺旋与左手双螺旋结构片段的衔接结构 (图1(c) ) 以及宽度为 $59 \AA$ 、螺距为 $27 \AA$ 的三级结构(图1(d)). 我们进行了重复 实验, 并用 STM 的势垒高度图技术对样品进行了测定和分析, 排除了图象是由基底石墨所造成的假象的 可能性.

儿十年以前, 就已知道在体外存在 DNA 的三链形态. 最近的研究认为这种形态在体内 亦存在, 并具有生物学的意义, 这引起了生物学家的兴趣 ${ }^{[4]}$. 但日前对这种三链形态的结构知 之蒁少. 虽然有人根据多核苗酸纤维的衍射 ${ }^{[5]}$ 、核磁共振 ${ }^{\left[{ }^{3}\right]}$ 的结果推测三链呈螺旋形式, 第三条链沿双螺旋的大沟在双螺旋的外部䀟绕而成, 但目前尚没有直接观察到其真实结构. 我们用 STM 直接观察的三链 DNA 结构并不支持上述模型, 而且据我们所知. DNA 经变 性:处理后由原来的右手双螺旋结构变成左手双螺旋和左、右螺旋在一条链上同时㐿在, 以及具 有螺旋特征的三级结构的直接观察, 尚未见报道.

本工作受到中国科学院“重中之重“项日的支持. 梁栋材、陈常庆、唐有祺教授在讨论中提出了很好的建议. 中国科学院化学研究所的黄桂珍、孙红、王培森、李人力等人在 STM 的实验技术方面参加了部分工作, 谨致谢意.

本文 1990 年 11 月 29 日收到. 


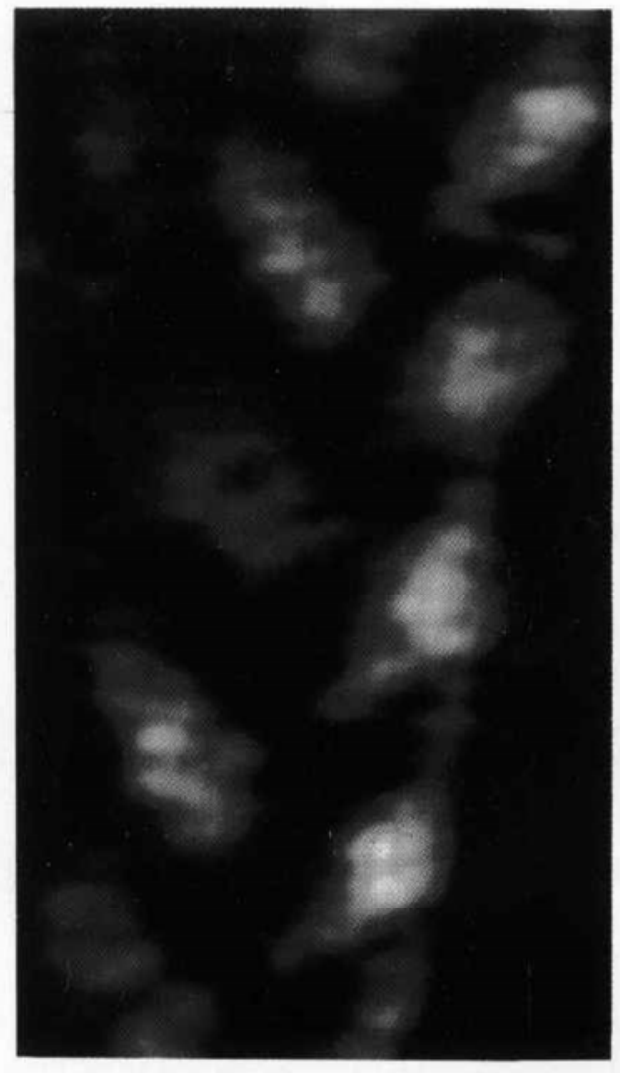

(a)

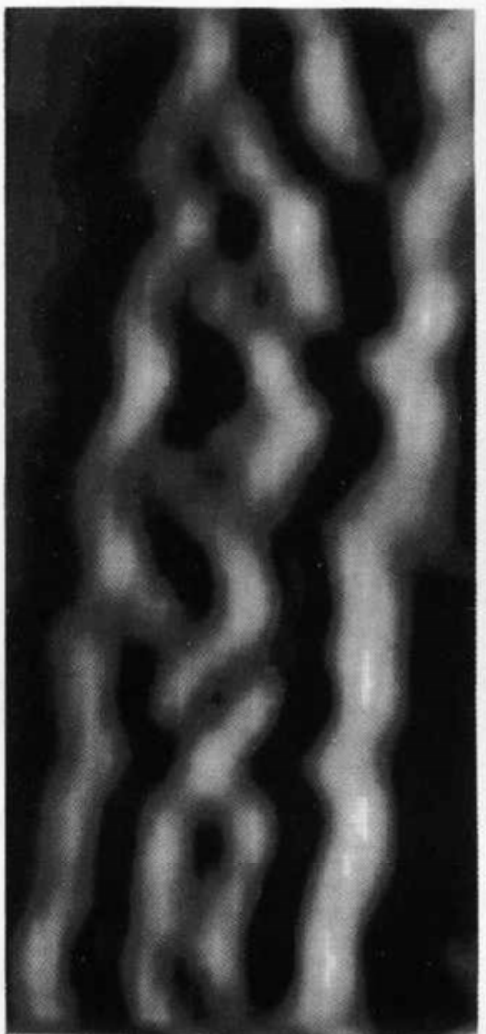

(b)

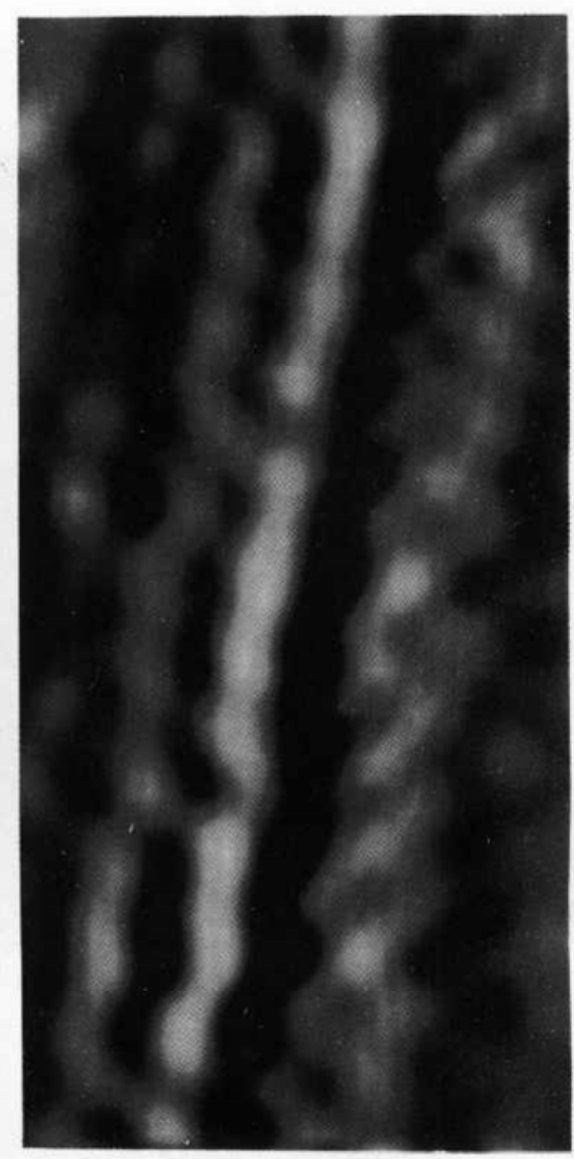

(c)

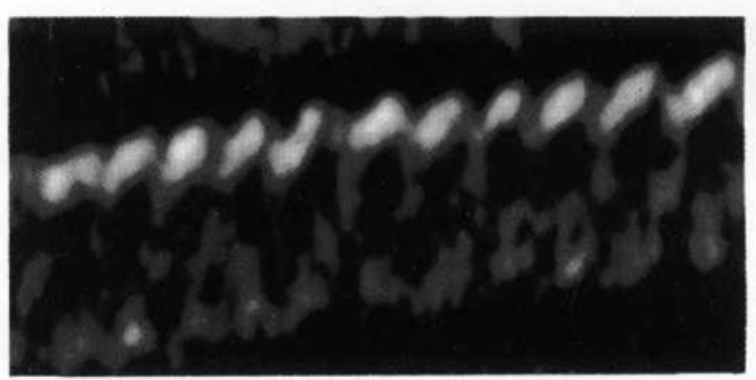

(d)

图 1 经变性处理的DNA 变异结构

(a) 韸状三链继绕结构, 扫描范围为 $47 \times 96 \AA$; (b) 双链片断与三链片断的衔接结构, 扫描范围为 $61 \times 147 \AA$;

(c)左右双螺旋衔接结构 (图中右侧链), 扫描范围为 $93 \times 177 \AA$; (d) 螺旋特征三级结构, 扫描范围为 $319 \times 98 \AA$

\section{参考文献}

[1] Beebe, T.P. et al., Science, 243(1989), 370.

[2] Arscott, P. G., Lee, G., Blloomfield, V.A., Evans, D. F., Nature, 339(1989), 494.

[3] 白春礼, 科学通报, 34(1989), 5:339.

[4] Pilch, D.S., et al., Proc.Natl.Acad.Sci.USA, 87(1990), 1942.

[5] Arnott, S., Selsing, E., J.Mol.Biol., 88(1974), 509. 